\title{
Association Between the G1001C Polymorphism in the GRIN1 Gene Promoter and Schizophrenia in the Iranian Population
}

Hamid Galehdari • Atefeh Pooryasin •

Alimohammad Foroughmand • Setareh Daneshmand •

Mostafa Saadat

Published online: 19 October 2008

(C) Humana Press 2008

Erratum to: J Mol Neurosci

DOI 10.1007/s12031-008-9148-5

The original publication mistakenly listed only the first author. The full author group is as follows: Hamid Galehdari, Ph.D; Atefeh Pooryasin; Alimohammad Foroughmand; Setareh Daneshmand; Mostafa Saadat.

All authors are affiliated with Shahid Chamran University, Ahvaz, Iran

The online version of the original article can be found at http://dx.doi. org/10.1007/s12031-008-9148-5.

H. Galehdari $(\bowtie) \cdot$ A. Pooryasin $\cdot$ A. Foroughmand •

S. Daneshmand $\cdot$ M. Saadat

Shahid Chamran University,

Ahvaz, Iran

e-mail: galehdari@scu.ac.ir 